\title{
Effect of angiotensin II on iron-transporting protein expression and subsequent intracellular labile iron concentration in human glomerular endothelial cells
}

\author{
Soichiro Tajima ${ }^{1}$, Koichiro Tsuchiya ${ }^{2}$, Yuya Horinouchi ${ }^{1}$, Keisuke Ishizawa ${ }^{1}$, Yasumasa Ikeda ${ }^{1}$, \\ Yoshitaka Kihira $^{1}$, Masayuki Shono ${ }^{3}$, Kazuyoshi Kawazoe ${ }^{4}$, Shuhei Tomita ${ }^{1}$ and Toshiaki Tamaki ${ }^{1}$
}

Angiotensin II (Ang II)-induced endothelial injury, which is associated with atherosclerosis, is believed to be mediated by intracellular reactive oxygen species (ROS) through stimulation of nicotinamide adenine dinucleotide phosphate oxidase (NOX). Iron is essential for the amplification of oxidative stress. In this study, we investigated whether Ang II altered iron metabolism and whether the Ang II-induced endothelial injury is attributable to changes in iron metabolism of human glomerular endothelial cells (HGECs). When $90 \%$ iron-saturated human transferrin $(90 \% \mathrm{Tf}$ ) was applied to HGECs without Ang II, the labile ferrous iron level was same as the effect of control in spite of a significant increase in the total cellular iron concentration. Treatment with Ang II and $30 \%$ Tf or $90 \%$ Tf significantly $(P<0.01)$ increased the intracellular iron concentration, as well as labile ferrous iron and protein oxidation levels, compared with the effect of separate administration of each compound. Ang II treatment facilitated the protein expression of the Tf receptor, divalent metal transporter 1 , and ferroportin 1 in a dose- and timedependent manner. It was also found that simultaneous exposure of HGECs to Ang II and $90 \%$ Tf accelerated hydroxyl radical production, as shown by using an electron paramagnetic resonance spectrometer. These results suggest that Ang II not only induces production of ROS by NOX activation but also iron incorporation followed by an increase in labile iron in HGECs. Both of these events may participate in the progression of oxidative stress because of endothelial cell dysfunction through ferrous iron-mediated ROS generation.

Hypertension Research (2010) 33, 713-721; doi:10.1038/hr.2010.63; published online 30 April 2010

Keywords: angiotensin II; human glomerular microvascular endothelial cells; iron metabolism; labile iron pool; transferrin

\section{INTRODUCTION}

The renin-angiotensin system is an enzymatic cascade that results in the formation of angiotensin II (Ang II). Ang II is a critical peptide in blood pressure control, sodium and water homeostasis, and cardiovascular function and structure, and it has been implicated in the pathophysiology of hypertension, congestive heart failure, diabetic nephropathy and vascular diseases, including atherosclerosis. ${ }^{1}$ In addition, Ishizaka et al. ${ }^{2}$ reported that 7-day Ang II infusion with an osmotic minipump-induced mRNA expression of iron metabolism-related genes, including transferrin receptor (TfR), divalent metal transporter 1 (DMT1), ferroportin 1 (FPN1) and hepcidin, in the rat kidney.

Recent identification of the iron transport proteins TfR, DMT1 and FPN1 has enabled more rigorous studies of intracellular iron regulation. TfR localizes to the plasma membrane, traps diferric $\mathrm{Tf}^{3}{ }^{3}$ and then internalizes it by receptor-mediated endocytosis. ${ }^{4}$ Ferric iron $\left(\mathrm{Fe}^{3+}\right)$ is released from Tf into an acidic compartment in endosomes. ${ }^{5}$ Iron is then bound by its membrane acceptor, DMT1, and is translocated to the cytosolic side of the plasma membrane in the ferrous iron $\left(\mathrm{Fe}^{2+}\right)$ form. ${ }^{6,7} \mathrm{FPN} 1$ exports iron across the cell membrane and donates the metal to Tf after oxidation by a membrane-bound ferroxidase. ${ }^{8}$ Under non-pathological conditions, intracellular iron levels are primarily regulated by these transporters and iron-binding proteins, including lactoferrin and ferritin, by tightly sequestering iron, ${ }^{9}$ and free iron catalyzes the formation of reactive oxygen species (ROS).

Nevertheless, a small amount of iron ( $<5 \%$ of total cellular iron) is evidently free within the cytoplasm and is designated as the labile iron pool (LIP). ${ }^{10}$ The LIP is defined as a low-molecular-weight pool of weakly chelated iron that rapidly passes through cells. ${ }^{11}$ The LIP

${ }^{1}$ Department of Pharmacology, The Institute of Health Bioscience, The University of Tokushima Graduate School, Tokushima, Japan; ${ }^{2}$ Department of Medical Pharmacology, The Institute of Health Bioscience, The University of Tokushima Graduate School, Tokushima, Japan; ${ }^{3}$ Support Center for Advanced Medical Sciences, The Institute of Health Bioscience, The University of Tokushima Graduate School, Tokushima, Japan and ${ }^{4}$ Department of Clinical Pharmacy, The Institute of Health Bioscience, The University of Tokushima Graduate School, Tokushima, Japan

Correspondence: Dr T Tamaki, Department of Pharmacology, The Institute of Health Bioscience, The University of Tokushima Graduate School, 3-18-15, Kuramoto, Tokushima 770-8503, Japan.

E-mail: tamaki@basic.med.tokushima-u.ac.jp

Received 6 October 2009; revised 17 January 2010; accepted 3 March 2010; published online 30 April 2010 
consists of both ferrous iron and ferric iron and a variety of small molecules, including organic anions, polypeptides and phospholipids as ligands, and comprises a transit pool that keeps iron available for the synthesis of iron-containing proteins. ${ }^{12}$ However, at the same time, the LIP also promotes the formation of ROS $^{13}$ because of the presence of redox-active irons through Fenton and Harber-Weiss reactions. Furthermore, it is well recognized that Ang II is a representative stimulator of nicotinamide adenine dinucleotide phosphate oxidase (NOX), a heteromeric enzyme complex broadly distributed throughout cardiovascular and other tissues. ${ }^{14,15}$ Once activated, NOX uses intracellular nicotinamide adenine dinucleotide phosphate and nicotinamide adenine dinucleotide as electron donors to catalyze the single electron reduction of extracellular molecular oxygen to superoxide anion $\left(\mathrm{O}_{2}{ }^{\bullet-}\right)$. This radical in turn is rapidly converted by superoxide dismutase to hydrogen peroxide $\left(\mathrm{H}_{2} \mathrm{O}_{2}\right)$, a more stable, membranepermeant ROS that widely participates in signaling ${ }^{14,15}$ and is a mediator of tissue injury ${ }^{16,17}$ not only in phagocytes but also in nonphagocytic cells including mesangial cells, ${ }^{18,19}$ vascular smooth muscle cells ${ }^{20}$ and vascular endothelial cells. ${ }^{21}$

In addition, the existence of trace amounts of labile irons can catalyze the reaction of $\mathrm{O}_{2}{ }^{\bullet-}$ and $\mathrm{H}_{2} \mathrm{O}_{2}$ as follows:

ferrous iron participates in the Fenton reaction:

$\mathrm{H}_{2} \mathrm{O}_{2}+\mathrm{Fe}^{2+} \rightarrow \mathrm{Fe}^{3+}+{ }^{-} \mathrm{OH}+{ }^{\bullet} \mathrm{OH}$ (Fenton reaction).

ferric iron is reduced by $\mathrm{O}_{2}^{\bullet-}$ and is then changed to ferrous iron: $\mathrm{O}_{2}^{\bullet-}+\mathrm{Fe}^{3+} \rightarrow \mathrm{Fe}^{2+}+\mathrm{O}_{2}$.

Overall, iron catalyzes the production of the hydroxyl radical $(\bullet \mathrm{OH})$, the most powerful oxidant within cells.

$\mathrm{H}_{2} \mathrm{O}_{2}+\mathrm{O}_{2}{ }^{\bullet-}-\mathrm{Fe} \rightarrow{ }^{-} \mathrm{OH}+{ }^{\bullet} \mathrm{OH}+\mathrm{O}_{2}$ (Harber-Weiss reaction). ${ }^{22}$

Iron-dependent generation of oxygen-derived free radicals is known to induce oxidation of proteins, lipids and lipoproteins, nucleic acids, carbohydrates and other cellular components. ${ }^{11,23}$ The $\bullet \mathrm{OH}$ radical is recognized as the main source of oxidative damage to cells. ${ }^{24,25}$

Furthermore, $\mathrm{O}_{2}{ }^{\bullet-}$ oxidizes and $(4 \mathrm{Fe}-4 \mathrm{~S})$ clusters of dehydratases, such as aconitases and fumarase $\mathrm{A}$ and $\mathrm{B}$, and this oxidation process facilitates iron release in the ferrous form, and then the liberated ferrous iron participates in the Fenton reaction. ${ }^{25}$ Similarly, ferritin ${ }^{26}$ and $\mathrm{Tf}^{27}$ release ferrous iron by $\mathrm{O}_{2}^{\bullet-}$.

It has been established that Ang II-induced oxidative stress depends on the generation of $\mathrm{O}_{2}{ }^{\bullet-}$ by activation of $\mathrm{NADP}(\mathrm{H})$ oxidases through the Ang II type $1\left(\mathrm{AT}_{1}\right)$ receptor. ${ }^{28,29}$ However, we hypothesized that Ang II induces not only $\mathrm{O}_{2}{ }^{\bullet-}$ production but also iron incorporation into cells and facilitates ferrous iron formation. These in turn interact with each other to promote cell dysfunctions through the iron-mediated ROS generation system. In clinical practice, certain organ dysfunctions such as hepatitis C infection, non-alcoholic steatohepatitis, and chronic kidney disease are associated with iron overload, ${ }^{30,31}$ and it has been reported that an $\mathrm{AT}_{1}$ receptor blocker attenuated non-alcoholic steatohepatitis progression ${ }^{32}$ and abnormal iron deposition in the kidney. ${ }^{31}$

To address our hypothesis, we analyzed whether Ang II treatment modulates iron transport proteins so as to increase the intracellular ferrous iron content followed by oxidative stress and whether the $\mathrm{AT}_{1}$ receptor blocker olmesartan reduces both intracellular iron content and ferrous iron in human glomerular endothelial cells (HGECs).

\section{METHODS}

\section{Materials}

Ang II, 30\% iron-saturated human Tf (30\% Tf), which is the mean value of healthy individuals, ${ }^{33}$ and 1,10-phenanthroline were purchased from SigmaAldrich (St Louis, MO, USA). Olmesartan was provided by Daiichi-Sankyo
Pharmaceutical (Tokyo, Japan). Phen Green SK diacetate (PG SK) was purchased from Molecular Probes Europe BV (Leiden, The Netherlands). 5,5-Dimethyl-1-pyrroline- $N$-oxide (DMPO) was purchased from Labotech (Tokyo, Japan). Phosphate-buffered saline (PBS: phosphate $1 \mathrm{~mm}, \mathrm{NaCl}$ $150 \mathrm{~mm}, \mathrm{pH}$ 7.4) was deionized with chelex-100 (Bio-Rad, Hercules, CA, USA). All other chemicals were of reagent grade and obtained from commercial sources, and were used without further purification.

\section{Endothelial cell culture}

HGECs were purchased from Cell Systems (Kirkland, WA, USA), and stored under cryopreservation. HGECs were plated in $75-\mathrm{cm}^{2}$ type collagen-coated flasks (Becton Dickinson Labware, Lincoln Park, NJ, USA) after thawing, and cultured in 10\% serum CSC complete medium (Cell Systems) without antibiotics. The cells were grown in a humidified atmosphere in $5 \% \mathrm{CO}_{2}$ and $95 \%$ air at $37^{\circ} \mathrm{C}$. The medium was changed every 2 days. The cells were subcultured after reaching confluency by $0.25 \mathrm{mg} \mathrm{ml}^{-1}$ trypsin/ethylenediamine tetraacetic acid. Passages 4-6 were used for experiments. All experiments, except as noted, were performed under the above culture conditions after cells had reached confluence, as judged by phase-contrast microscopy.

\section{Preparation of $\mathbf{9 0 \%}$ iron-saturated human Tf $(\mathbf{9 0 \%}$ Tf)}

Ninety percent Tf was prepared by the method of Ponka with slight modifications. ${ }^{34} \mathrm{Tf}(0.75 \mathrm{~mol})$ and ferric citrate $(1 \mathrm{~mol})$ were dissolved in $0.1 \mathrm{M}$ $\mathrm{NaHCO}_{3}, \mathrm{pH} 7.4$, and the solution was maintained at room temperature for $3 \mathrm{~h}$, and then dialyzed against a large excess of PBS. As excess iron was removed during dialysis, the value of the $\mathrm{Tf}$ saturation was estimated using a molar absorption coefficient of 4620 at $470 \mathrm{~nm} .^{35}$

\section{Measurement of the intracellular total iron concentration}

HGECs were cultured in $60 \mathrm{~mm}$ collagen IV-coated culture dishes (IWAKI, Tokyo, Japan). Culture medium was removed by vacuum suction, and the cells were then rinsed twice with ice-cold PBS. Excess PBS was removed from the dishes by vacuum suction, and the culture dishes with attached cells were placed in an $-80^{\circ} \mathrm{C}$ freezer to promote membrane disruption. After freezing and thawing, cells were harvested by scraping with $500 \mu \mathrm{l}$ of $2 \%$ Triton X-100. The cell milieu from each dish was transferred by plastic transfer pipette into a micro-centrifuge tube, and cells were lysed by keeping them at room temperature for $1 \mathrm{~h}$ with intermittent vortex mixing, and then centrifugation at $14000 \times g$ for $20 \mathrm{~min}$ at $4{ }^{\circ} \mathrm{C}$. The supernatant fraction was dissolved five times with $2 \%$ Triton X-100 and aliquots were taken for determination of the protein concentration, and the remaining sample was then subjected to a polarized zeeman atomic absorption spectrophotometer (Z-5710 Polarized Zeeman, Hitachi, Tokyo, Japan) opening in graphite furnace mode, using a Fe hollow cathode lamp for iron concentration measurement at a wavelength of $302.1 \mathrm{~nm}$ with a $0.2 \mathrm{~nm}$ slit width and $15 \mathrm{~mA}$ lamp current. The following times and temperatures were used for the iron measurement: drying at $140^{\circ} \mathrm{C}$ for $40 \mathrm{~s}$; ashing at $1050{ }^{\circ} \mathrm{C}$ for $20 \mathrm{~s}$ and atomization at $2400^{\circ} \mathrm{C}$ for $5 \mathrm{~s}$. Calibration curves were obtained by using standard iron solutions (Wako, Tokyo, Japan).

\section{Protein determination}

Protein determination was performed according to the method of Bradford using a Bio-Rad protein assay kit (Bio-Rad) with bovine serum albumin as standard. ${ }^{36}$

\section{Preparation of cell lysate and western blotting}

After the experimental treatments outlined in the figure legends, cells were washed twice with PBS and lysed with cell lysis buffer (20 mm Tris-HCl, pH7.4, $150 \mathrm{~mm} \mathrm{NaCl}, 1 \mathrm{~mm}$ ethylenediamine tetraacetic acid, $1 \mathrm{~mm}$ ethyleneglycol tetraacetic acid, $1 \%$ Triton X-100, $2.5 \mathrm{~mm}$ sodium pyrophosphate, $1 \mathrm{~mm}$ $\beta$-glycerophosphate, $1 \mathrm{~mm}$ sodium orthovanadate, $1 \mu \mathrm{g} \mathrm{ml}^{-1}$ leupeptin and $1 \mathrm{~mm}$ phenylmethylsulfonyl fluoride). After freeze-thawing, lysed cells were transferred to microcentrifuge tubes, sonicated (Handy Sonic UR-20 P; Tomy Seiko, Tokyo, Japan) on ice, and centrifuged at $20000 \times g$ for $20 \mathrm{~min}$ at $4{ }^{\circ} \mathrm{C}$ then stored at $-80^{\circ} \mathrm{C}$ until immunoblotting.

For western blotting, cell lysates were subjected to sodium dodecylsulfatepolyacrylamide gel electrophoresis, and proteins were transferred to nitrocellulose membranes. The membranes were blocked for $1 \mathrm{~h}$ at room temperature 
with $5 \%$ bovine serum albumin. The blots were then incubated for $12 \mathrm{~h}$ with antihuman Tf receptor antibody (1:1000, Zymed, San Francisco, CA, USA), anti-mouse DMT1 (+IRE) antibody (1:1000, Alpha Diagnostics, San Antonio, TX, USA) or anti-mouse FPN antibody (1:1000, Alpha Diagnostics), followed by incubation for $1 \mathrm{~h}$ with a secondary antibody (horseradish peroxidaseconjugated antibody). Immunoreactive bands were visualized using enhanced chemiluminescence (ECL; Amersham Pharmacia Biotech, Piscataway, NJ, USA) and were quantified by densitometry in the linear range of film exposure using a UMAX Astra 2200 scanner (UMAX Technologies, Fremont, CA, USA) and image J 1.31v software (National Institutes of Health, Bethesda, MD, USA) for quantification.

\section{Measurement of intracellular labile ferrous iron}

The intracellular chelatable or labile ferrous iron was determined using the fluorescent probe, PG SK, ${ }^{37}$ with slight modifications. HGECs were cultured in $10 \%$ serum CSC complete medium on a collagen-coated glass bottom dish (MATSUNAMI, Osaka, Japan) at $70 \%$ confluence. To introduce the probe, culture media was removed and washed twice with PBS containing $2 \mathrm{~mm} \mathrm{CaCl} 2$ and $0.5 \mathrm{~mm} \mathrm{MgCl}_{2}$ (defined as PBS(+)), then replaced with $1 \mathrm{ml} \mathrm{PBS}(+)$ along with $20 \mu \mathrm{M}$ PG SK diacetate for $20 \mathrm{~min}$ at $37^{\circ} \mathrm{C}$. The cells were then washed with PBS(+) twice, green fluorescence was examined in the presence of $1 \mathrm{ml}$ PBS(+) using a Leica fluorescence microscope (ZEISS Axiovert $200 \mathrm{M}$, ZEISS, Oberkochen, Germany) with a digital CCD camera (Ex: BP470/400, Em: BP520/550) for the initial fluorescence measurement. Immediately after the measurement of the initial fluorescence, $2 \mathrm{~mm}$ 1,10-phenanthroline was added and incubated for $10 \mathrm{~min}$ at $37^{\circ} \mathrm{C}$, then a second fluorescence was obtained under the same conditions. The average fluorescence intensity of each cell was calculated using image J, and the intracellular chelatable or labile ferrous iron level was expressed as the difference of the fluorescence intensity between the second and initial measurements.

\section{Electron paramagnetic resonance (EPR) measurements of ROS generation in HGECs}

EPR-spin trapping technique was adopted to clarify the ROS production from HGECs as described previously, with a slight modification. ${ }^{38}$ HGECs were seeded $\left(1 \times 10^{5} \mathrm{cells} \mathrm{cm}^{-2}\right)$ and grown to subconfluence in $60-\mathrm{mm}$ culture dishes in CSC growth medium-10\% fetal bovine serum. Cells were pretreated with or without $90 \% \operatorname{Tf}(50 \mu \mathrm{M})$ for $5 \mathrm{~min}$, then treated with or without Ang II ( $1 \mathrm{~nm}$ ) for $6 \mathrm{~h}$ at $37^{\circ} \mathrm{C}$, and then cells were washed twice with PBS. Each sample was incubated with $100 \mathrm{mM} \mathrm{DMPO}$ for $5 \mathrm{~min}$ at $37^{\circ} \mathrm{C}$, then transferred to three sections of glass capillary ( $10 \mu$ l, Drummond, Broomall, PA, USA) and set into the EPR cavity for the measurements. A JEOL EPR spectrometer (JES-TE 300, JEOL, Tokyo, Japan) with an X-band cavity was used to collect all EPR spectra. Hyperfine coupling constants were obtained with the computer program Winsim. ${ }^{39}$ Typical instrument conditions were: $20 \mathrm{~mW}$ microwave power, 1.25 Gauss modulation amplitude, $0.3 \mathrm{~s}$ time constant, $100 \mathrm{kHz}$ modulation frequency, 100 Gauss scan range and 2 min sweep time.

\section{Protein carbonyl detection by immunoblotting}

To quantify the oxidative protein modification, we introduced an enzymelinked immunosorbent assay according to the method of Buss et al., ${ }^{40}$ with slight modifications. Derivatization for detection of protein carbonyls was performed by mixing one volume of cell lysate with the same volume of $12 \%$ sodium dodecylsulfate for solubilization, then treated with two volumes of $20 \mathrm{~mm}$ 2,4-dinitrophenylhydrazine dissolved in 10\% trifluoroacetic acid. Subsequently, the samples were incubated for $15 \mathrm{~min}$ at room temperature and then neutralized by adding 1.5 volumes of $2 \mathrm{~m}$ Tris base dissolved in $30 \%$ glycerol. The carbonyl-derivatized samples were loaded directly onto a $12 \%$ gel for sodium dodecylsulfate- polyacrylamide gel electrophoresis. Proteins were then transferred onto nitrocellulose membranes and the 2,4-dinitrophenyl moiety was detected by rabbit anti-2,4-dinitrophenyl antibody (Chemicon Oxyblot Kit, Millipore, Billerica, MA, USA). Bands containing carbonyl groups were visualized a luminol-enhanced chemoluminescence system and exposure to X-ray film.

\section{Statistical analysis}

Values are reported as the means \pm s.d. from experiments performed on five different occasions. Two-way analysis of variance was used to determine the significance among groups, after which a modified $t$-test along with Bonferroni's post hoc test was used for comparison between individual groups. A value of $P<0.05$ was considered to be statistically significant.

\section{RESULTS}

Effect of Ang II on intracellular total iron concentration in HGECs We first examined the effect of $1 \mathrm{~nm}$ Ang II on intracellular total iron concentration in HGECs. As shown in Figure 1a, co-treatment with $1 \mathrm{nM}$ Ang II and $50 \mu \mathrm{M} 30 \% \mathrm{Tf}$ for $24 \mathrm{~h}$ resulted in a significant increase in intracellular iron concentration (control: $0.52 \pm 0.10 \mathrm{pmol}$ Fe $\mu \mathrm{g}^{-1}$ protein, $1 \mathrm{~nm}$ Ang II $+30 \%$ Tf: $1.00 \pm 0.18 \mathrm{pmol} \mathrm{Fe} \mu \mathrm{g}^{-1}$ protein, $P<0.05)$. Neither $1 \mathrm{~nm}$ Ang II nor $50 \mu \mathrm{m} 30 \% \mathrm{Tf}$ alone stimulated iron uptake into HGECs. In contrast, $1 \mu \mathrm{M}$ olmesartan, a potent Ang II type 1 receptor blocker, inhibited the iron uptake stimulated by the
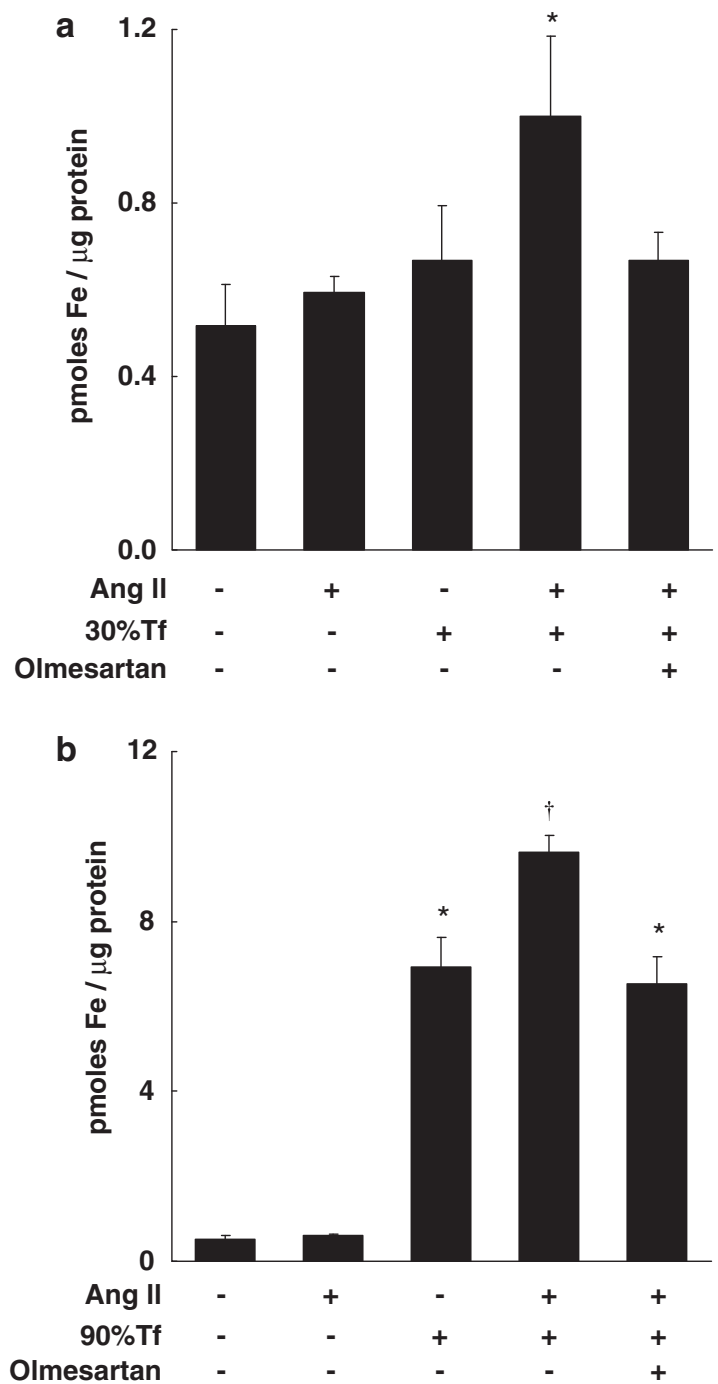

Figure 1 Effect of Ang II on intracellular total iron concentration in HGECs. Cells were treated with Ang II (1 nm) for $24 \mathrm{~h}$ with or without $30 \% \mathrm{Tf}$ $(50 \mu \mathrm{m}$; a) or $90 \% \mathrm{Tf}(50 \mu \mathrm{m}$; b) for $24 \mathrm{~h}$. For olmesartan treatment, $1 \mu \mathrm{m}$ olmesartan was added $30 \mathrm{~min}$ before the Ang II stimulation. Total iron concentration was expressed as pmol of iron per $\mathrm{mg}$ of protein. Data for three individual experiments are expressed as means \pm s.d. ${ }^{*} P<0.01$ vs. the non-stimulated control cells, ${ }^{\dagger} P<0.01$ vs. $90 \% \mathrm{Tf}(50 \mu \mathrm{m})$ without Ang II. 
combination of $1 \mathrm{~nm}$ Ang II and 30\% Tf to the control level. Treatment of HGECs with $50 \mu \mathrm{M} 90 \%$ Tf (Figure 1b) for $24 \mathrm{~h}$ resulted in a significant increase in cellular iron concentration compared with the control (control: $0.52 \pm 0.10 \mathrm{pmol} \mathrm{Fe} \mu \mathrm{g}^{-1}$ protein, 90\% Tf: $6.90 \pm$ $0.70 \mathrm{pmol} \mathrm{Fe} \mu \mathrm{g}^{-1}$ protein, $\left.P<0.05\right)$. The iron uptake stimulated by $50 \mu \mathrm{m} 90 \% \mathrm{Tf}$ was further increased by the addition of $1 \mathrm{~nm}$ Ang II, and this Ang II-induced elevation was completely suppressed by treatment with $1 \mu \mathrm{M}$ olmesartan.

Time course for the protein expression of TfR, DMT1 and FPN1 in HGECs stimulated by Ang II

As administration of Ang II to rats increased TfR, DMT1 and FPN1 mRNA levels in the kidney, ${ }^{2}$ we examined the effect of 1 nM Ang II on iron metabolism-related protein levels in HGECs. As shown in Figure 2a, bands representing TfR, DMT1 and FPN1 proteins were recognized at $95 \mathrm{kDa}, 65 \mathrm{kDa}$ and $60 \mathrm{kDa}$, respectively. TfR gradually increased (peaking at $12 \mathrm{~h}$ ) and then decreased. DMT1 showed a gradual increase after Ang II treatment with a peak at $6 \mathrm{~h}$ and then declined. FPN1 was constant until $6 \mathrm{~h}$ and then slowly increased until the end of the experiment $(24 \mathrm{~h})$. These are summarized in the lower panel of Figure $2 \mathrm{a}$.

Concentration response curves for the expression of TfR, DMT1 and FPN1 proteins in HGECs stimulated by Ang II

Next, we determined the dependence of TfR, DMT1 and FPN1 protein expression levels in HGECs on concentration of Ang II (0.1-100 nM). TfR, DMT1 and FPN1 expression levels were determined for incubation periods of $12 \mathrm{~h}, 6 \mathrm{~h}$ and $24 \mathrm{~h}$, respectively. The protein expression levels of these three samples were significantly increased in a concentration-dependent manner. The results are summarized in the lower panel of Figure $2 b$.

\section{Effect of olmesartan on Ang II-induced TfR, DMT1 and FPN1 expression in HGECs}

To clarify the role of $\mathrm{AT}_{1}$ receptor in the upregulation of $\mathrm{TfR}$, DMT1 and FPN1 proteins by Ang II, we examined the effect of olmesartan, a potent $\mathrm{AT}_{1}$ receptor blocker, on Ang II-induced iron metabolism-related protein expression in HGECs. The cells were pretreated with $1 \mu \mathrm{M}$ olmesartan for $30 \mathrm{~min}$. After the cells had been washed, they were then treated with $1 \mathrm{~nm}$ Ang II for $12 \mathrm{~h}$ (TfR), 6h (DMT1) and 24h (FPN1). All three proteins were significantly upregulated by Ang II treatment as shown in Figure $2 b$, and these increases were completely abolished by pretreatment with olmesartan (Figure 2c).

\section{Effect of Ang II on labile iron level in HGECs}

We then measured labile ferrous iron by using PG SK. Intracellular fluorescence under control conditions (Figure 3a) was dependent on intracellular free PG SK, whereas the fluorescence after 1,10phenanthroline treatment (Figure $3 \mathrm{e}$ ) depicted total (=free plus ferrous iron-chelated PG SK) PG SK concentration, so the difference between the two figures indicated the amount of intracellular basal labile ferrous iron levels. ${ }^{41}$

HGECs were treated with or without $1 \mathrm{~nm}$ Ang II in the presence or absence of Tf (30 and 90\%) for $24 \mathrm{~h}$. Then $20 \mu \mathrm{M}$ PG SK was added and initial fluorescence was measured (Figures $3 \mathrm{a}-\mathrm{d}$ ). The second fluorescence measurement was carried out after treatment with $2 \mathrm{~mm}$ 1,10-phenanthroline (Figures $3 \mathrm{e}-\mathrm{h}$ ) as described in Methods section. a

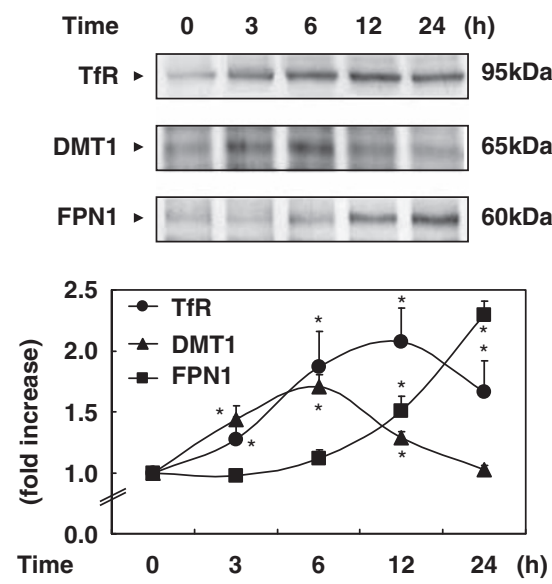

b

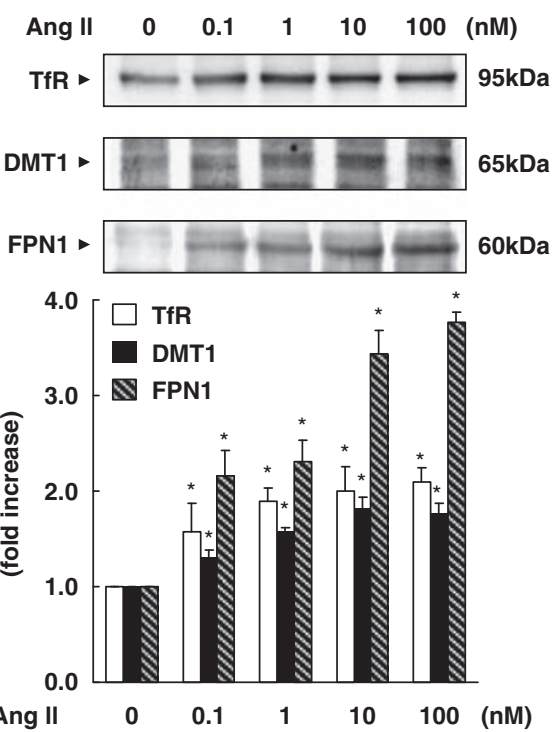

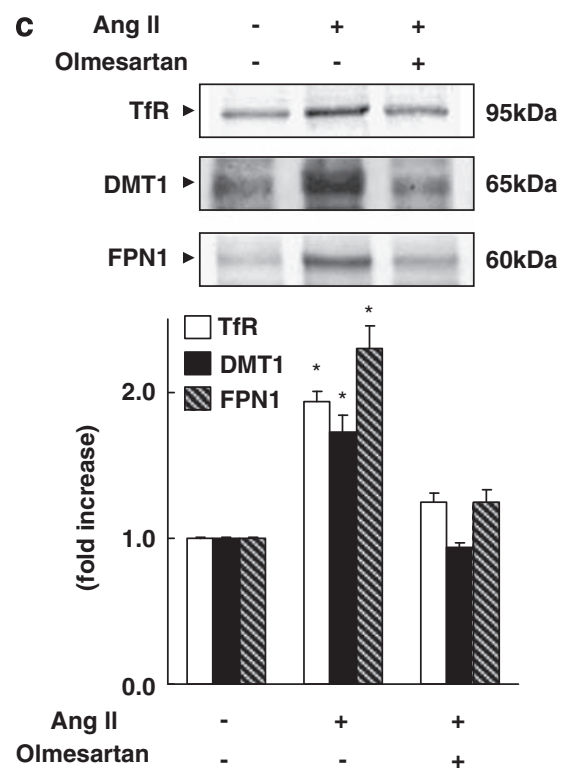

Figure 2 Effects of Ang II on TfR, DMT1 and FPN1 protein levels in HGECs. (a) Time courses of Ang II-induced expression of TfR, DMT1 and FPN1 protein levels. Cells were treated with Ang II (1 nM) for the indicated periods of time. Western blot analysis was performed as described in 'Methods' section. Upper panel shows representative blots of three proteins. Lower curve shows results of densitometric analysis. Values were normalized by arbitrarily setting the densitometry of control cells (time $=0$, without Ang II) to 1.0 (values are means \pm s.d., $n=5, * P<0.01$ vs. control cells at each time point). (b) Ang II induces a concentration-dependent increase in TfR, DMT1 and FPN1 protein levels in HGECs. Cells were treated with the indicated concentration of Ang II for $12 \mathrm{~h}$ for TfR, $6 \mathrm{~h}$ for DMT1 and $24 \mathrm{~h}$ for FPN1. Upper panel shows representative blots of three proteins. Lower graph shows the results of densitometric analysis. Values were normalized by arbitrarily setting the densitometry of control cells (without Ang II) to 1.0 (values are means \pm s.d., $n=5$, ${ }^{*} P<0.01$ vs. control cells.). (c) Effect of olmesartan on Ang II-induced expression of TfR, DMT1 and FPN1. Cells were pretreated with or without olmesartan $(1 \mu \mathrm{m})$ for $30 \mathrm{~min}$ followed by treatment with or without Ang II ( $1 \mathrm{~nm}$ ) for $12 \mathrm{~h}$ for TfR, $6 \mathrm{~h}$ for DMT1 and $24 \mathrm{~h}$ for FPN1. Upper panel shows representative blots of three proteins. Lower graph shows the results of densitometric analysis. Values were normalized by arbitrarily setting the densitometry of control cells (without Ang II) to 1.0 (values are means \pm s.d., $n=5,{ }^{*} P<0.01$ vs. control). 

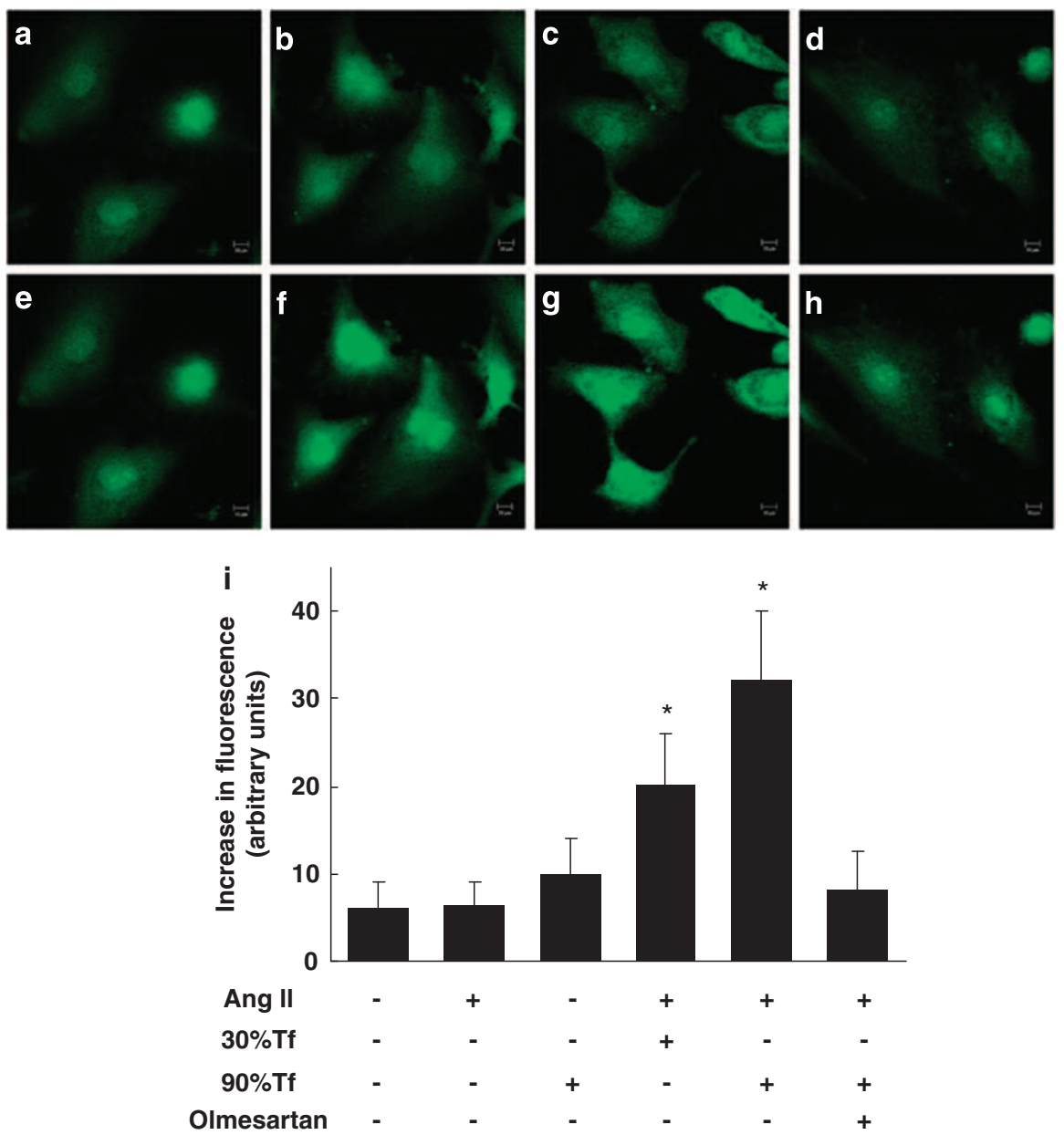

Figure 3 Ang II-induced changes in labile ferrous iron in HGECs. Cells were treated with (a, e) PBS (control), (b, f) $1 \mathrm{~nm}$ Ang II with $50 \mu \mathrm{m} 30 \%$ Tf, (c, g) $1 \mathrm{~nm}$ Ang II with $50 \mu \mathrm{m}$ 90\% Tf, (d, h) $1 \mathrm{~nm}$ Ang II with $50 \mu \mathrm{m} 90 \% \mathrm{Tf}$ and $1 \mu \mathrm{m}$ olmesartan (30-min pretreatment). After the addition of Ang II, cells were loaded with PG SK for $20 \mathrm{~min}$ and washed with PBS (+), and the fluorescence measurement was performed (a-d). Cells were then incubated with 1,10phenanthroline for $5 \mathrm{~min}$ and imaged (e-h) under the same exposure conditions as those in a-d. (i) Densitometric analysis of the increase in PG SK fluorescence of HGECs. Data for five individual experiments are expressed as means \pm s.d. ${ }^{*} P<0.01$ vs. control cells.

Neither 1 nм Ang II nor $50 \mu \mathrm{m}$ 90\% Tf alone stimulated labile ferrous iron levels in HGECs (Figure 3i). Interestingly, when 90\% Tf was added to the HGECs, labile iron level was the same as that in the control (Figure $3 \mathrm{i}$ ) in spite of a significant increase in total iron accumulation (Figure 1b). HGECs treated with Ang II and 30\% Tf showed a significant increase in cytosolic fluorescence by 1,10-phenanthroline treatment (Figures $3 \mathrm{~b}, \mathrm{f}$ and $\mathrm{i}$ ), indicating an increase in labile ferrous iron compared to the control. In addition, treatment with Ang II and 90\% Tf resulted in a greater increase in cytosolic fluorescence (Figures 3c, g and i). These increases were completely suppressed by pretreatment with $1 \mu \mathrm{M} \mathrm{AT}_{1}$ receptor blocker (Figures $3 \mathrm{~d}, \mathrm{~h}$ and i). The labile ferrous iron levels in HGECs treated with Ang II and $90 \%$ Tf gradually increased with time, peaked at $6 \mathrm{~h}$, and then declined (Figure 4).

EPR measurements of Ang II and 90\% Tf-induced DMPO/ ${ }^{\bullet} \mathrm{OH}$ generation in HGECs

As shown in Figures 5b and c, neither 1 nм Ang II nor $50 \mu \mathrm{m} 90 \% \mathrm{Tf}$ stimulation for $6 \mathrm{~h}$ generated detectable levels of DMPO spin adducts. However, HGECs treated with Ang II and 90\% Tf for $6 \mathrm{~h}$ showed 1:2:2:1 quartet EPR signals with hyperfine coupling constants of $\mathrm{a}^{\mathrm{N}}=\mathrm{a}^{\mathrm{H}}=1.49 \mathrm{mT}$ (Figure 5d), which were consistent with the reported values for the $\mathrm{DMPO} /{ }^{\bullet} \mathrm{OH}$ spin adduct. ${ }^{38,42}$ These findings indicated that Ang II and $90 \%$ Tf facilitated $\bullet$ OH generation in HGECs.

\section{Override effect of Ang II and Tf on carbonylation of proteins in HGECs}

Next, we analyzed the effect of Ang II and/or Tf on protein oxidative modifications in HGECs. HGECs were treated with or without $50 \mu \mathrm{M}$ Tf for $5 \mathrm{~min}$ before Ang II treatment and then incubated for $6 \mathrm{~h}$ in the presence or absence of $1 \mathrm{~nm}$ Ang II, followed by carbonyl detection with 2,4-dinitrophenylhydrazine as described in Methods section. As shown in Figure 6, protein oxidation occurred in the order of Ang II and $90 \% \mathrm{Tf}>$ Ang II and 30\% $\mathrm{Tf}>$ Ang II $>90 \% \mathrm{Tf}=$ control, suggesting that both iron and Ang II-stimulated protein oxidation in HGECs.

\section{DISCUSSION}

This study showed that Ang II induced not only production of ROS as reported previously but also iron incorporation followed by an increase in labile ferrous iron in HGECs, which participated in the production of ROS including ${ }^{\bullet} \mathrm{OH}$, resulting in protein oxidation. We also showed that the labile ferrous iron level was the same as that in the control in spite of a significant increase in total iron accumulation when $90 \%$ Tf was applied to the HGECs without Ang II. 

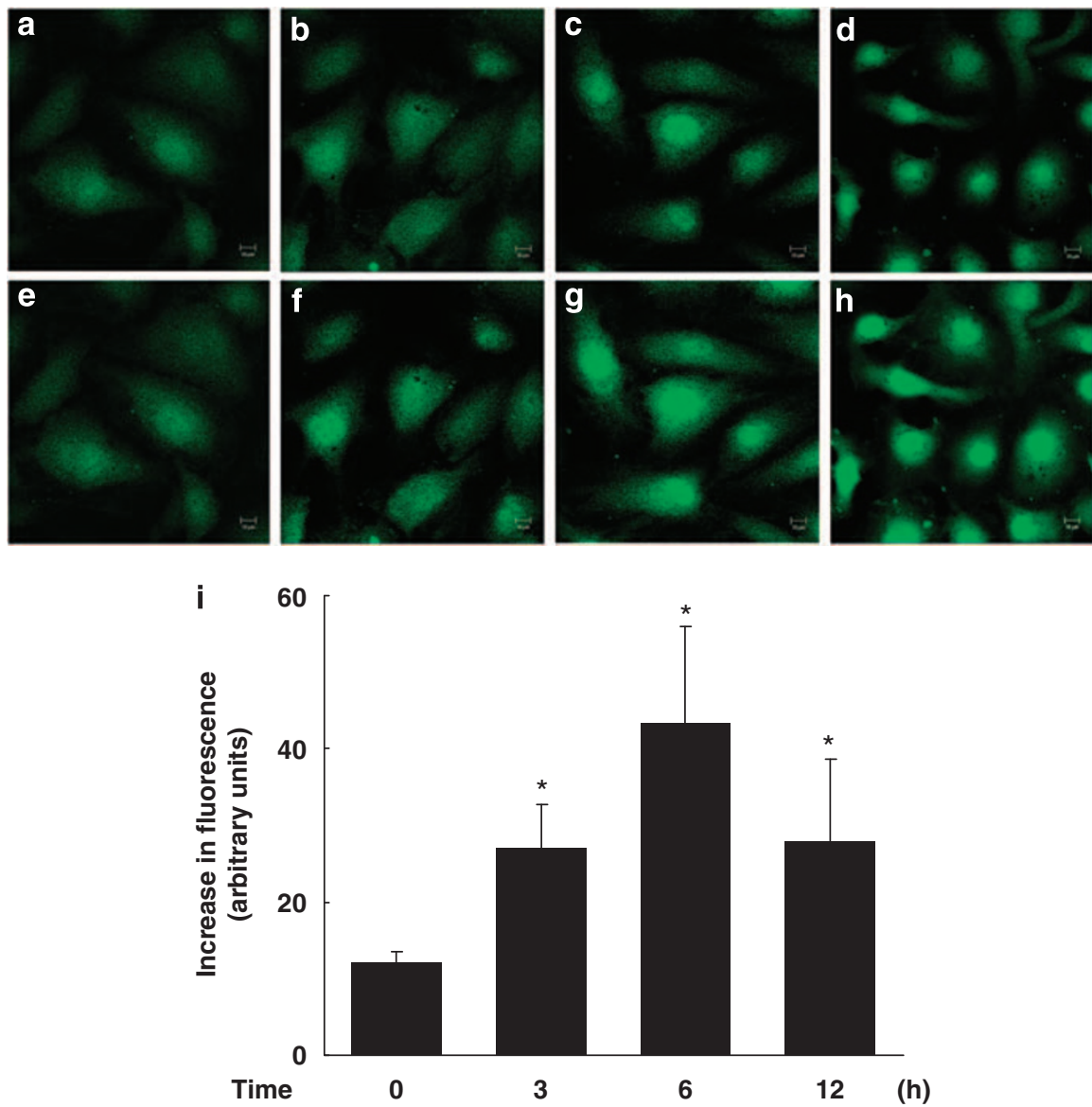

Figure 4 Time courses of Ang II-induced changes in labile ferrous iron in the presence of 90\% Tf in HGECs. Cells were treated with (a, e) PBS (control) or $1 \mathrm{~nm}$ Ang II with $90 \%$ Tf for $3 \mathrm{~h}(\mathbf{b}, \mathbf{f}), 6 \mathrm{~h}(\mathbf{c}, \mathbf{g})$ and $12 \mathrm{~h}(\mathbf{d}, \mathbf{h})$. Cells were treated as described in the legend of Figure 3. (i) Densitometric analysis of the increase in PG SK fluorescence of HGECs at different times after Ang II and Tf treatment. Data for three individual experiments are expressed as means \pm s.d. ${ }^{*} P<0.01$ vs. control cells.

Iron is an essential metal for hemoglobin synthesis in erythrocytes, oxidation-reduction reactions, and cellular proliferation. It is well known that excess iron accumulation causes organ dysfunction through the production of ROS. ${ }^{43}$ Body iron metabolism is a semiclosed system and is regulated by a number of molecules, including DMT1, hemoxygenase-1 (HO-1), FPN1, hephaestin, TfR, Tf, ferritin, hemosiderin, ZIP14 and hepcidin. ${ }^{44}$ Within cells, iron is stored in the proteins ferritin or hemosiderin. In addition to these proteins, approximately $5 \%$ of free iron is present in the form of the LIP within cells. ${ }^{10}$ The LIP consists of both ferrous iron and ferric iron, and these irons promote the formation of $\mathrm{ROS}^{13}$ through Fenton and HarberWeiss reactions.

In 2007, Ishizaka et al. reported that 7-day Ang II infusion induced the mRNA expression of iron metabolism-related genes, including TfR, DMT1, FPN1 and hepcidin, in the rat kidney. ${ }^{2}$ In addition, it is known that Ang II produces $\mathrm{O}_{2}{ }^{\bullet-}$ by the activation of $\mathrm{NOX}^{28,29}$ and that the $\mathrm{O}_{2}^{\bullet}{ }^{\bullet}$ can participate in ${ }^{\bullet} \mathrm{OH}$ formation by way of Fenton and Habor-Weiss reactions using iron as a catalyst. ${ }^{22}$ These phenomena leave little doubt that Ang II induces not only $\mathrm{O}_{2}{ }^{\bullet-}$ production but also iron incorporation into cells and facilitates ferrous iron formation, which in turn interact with each other to facilitate ironmediated generation of ROS. However, it is still unclear whether there is an interaction between iron metabolism and oxidative stress in cells.

In this study, we used HGECs because the expression of iron metabolism-related genes was reported in the kidney ${ }^{2}$ and because glomerular endothelial cells come into contact with the bloodstream, which contains $\sim 50 \mu \mathrm{M} \mathrm{Tf},{ }^{45}$ as well as i.p. injection of iron into rats and mice resulted in iron-induced free radical injury and cancer in the kidney. ${ }^{46}$ Renal tissue Ang II concentration has been reported to be $5.8 \mathrm{nmol} \mathrm{kg}^{-1}$ kidney wt, ${ }^{47}$ which is two orders higher than the serum Ang II level. First, we analyzed whether Ang II treatment increases intracellular iron concentration. When HGECs were stimulated with $1 \mathrm{~nm}$ Ang II or with $30 \% \mathrm{Tf}$, neither the intracellular iron concentration (Figure 1a) nor the intracellular labile ferrous iron concentration (Figure 3) was changed. If Tf uptake were only by TfR, the total iron concentration in $90 \%$ Tf-stimulated cells would be three times higher than that in 30\% Tf-stimulated cells. However, treatment with $90 \%$ Tf (Figure 1b) increased intracellular iron to a level 10 times higher than that in 30\% Tf-stimulated cells (Figure 1a), suggesting the existence of a Tf receptor-independent pathway, as reported previously. ${ }^{44,48} \mathrm{Co}-$ treatment with $1 \mathrm{~nm}$ Ang II and $50 \mu \mathrm{m} 30$ or $90 \%$ Tf for $24 \mathrm{~h}$ resulted in a significant increase in intracellular iron concentration compared with that in the case of Tf treatments (Figures la and b), and this increase was repressed by olmesartan, suggesting that Ang II facilitated iron incorporation into HGECs through the $\mathrm{AT}_{1}$ receptor, as reported in cardiac cells. ${ }^{49}$

Next, we analyzed the effects of Ang II on iron-metabolism proteins. In 2007, Ishizaka et al. reported upregulation of iron-metabolism-related mRNA, including TfR, DMT1 and FPN1, in rats treated with Ang $\mathrm{II}^{2}$ but it is still unclear whether these 
a

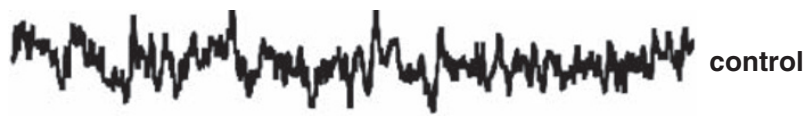

b

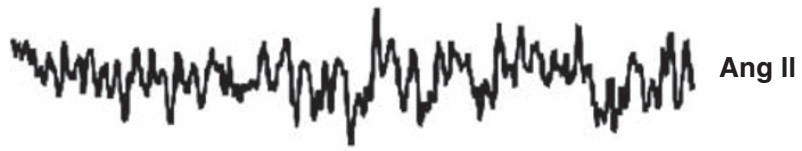

C

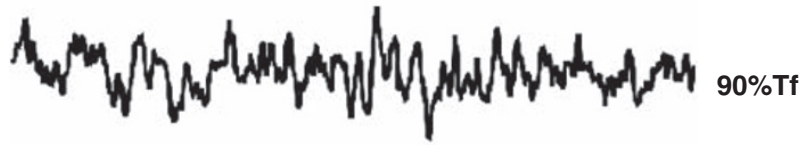

d

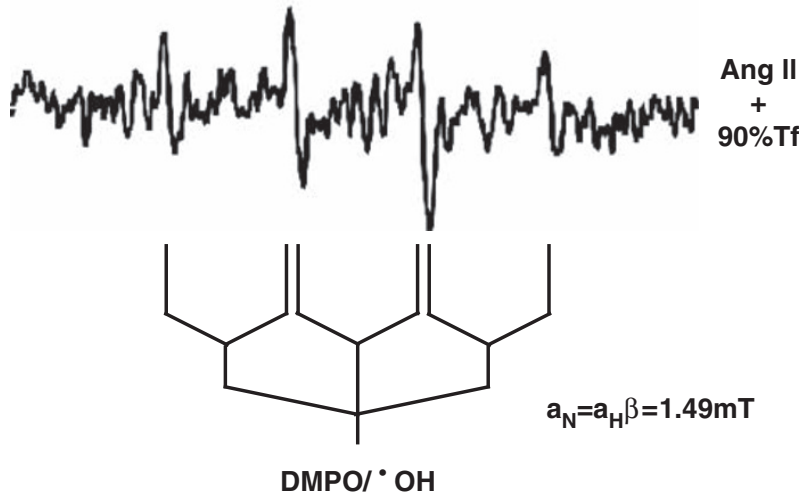

Figure 5 EPR spectra of $1 \mathrm{~nm}$ Ang $\|$ and 90\% Tf-treated HGECs with DMPO. (a) HGECs $\left(1 \times 10^{6} \mathrm{cells} \mathrm{ml}^{-1}\right)$ with $100 \mathrm{~mm}$ DMPO, (b) same as (a) but with $1 \mathrm{~nm}$ Ang II, (c) same as (a) but with $50 \mu \mathrm{m} 90 \% \mathrm{Tf}$, (d) same as (a) but with $50 \mu \mathrm{m} 90 \%$ Tf and $1 \mathrm{~nm}$ Ang II stimulation. Each experiment was repeated at least twice, and the results were similar.

proteins are actually upregulated. When HGECs were treated with $1 \mathrm{~nm}$ Ang II, these three proteins were increased in a time- and Ang II concentration-dependent manner, and these upregulation events were completely abolished in the presence of olmesartan (Figures $2 \mathrm{a}-\mathrm{c}$ ), indicating that the $\mathrm{AT}_{1}$ receptor contributed to the regulation of these proteins. These results were in good agreement with the results of iron incorporation into cells induced by Ang II (Figure 1). In addition, it is worth mentioning that even $0.1 \mathrm{~nm}$ Ang II, a concentration similar to that normally found in healthy human individuals, ${ }^{50}$ slightly stimulated these iron-regulating proteins. It has been reported that TfR, DMT1 and FPN1 are controlled by iron regulatory protein and iron responsive element systems ${ }^{51}$ and that the iron regulatory protein was stimulated by ROS. ${ }^{52}$ In addition, FPN1 is regulated by intracellular iron at the transcriptional level. ${ }^{53}$ The present data indicate that these proteins are upregulated in a sequential manner, that is, DMT1 protein was first to reach a peak at $6 \mathrm{~h}$ and then TfR protein reached a peak at $12 \mathrm{~h}$, but FPN1 protein level remained constant while TfR and DMT1 proteins were being upregulated (Figure 2a). These phenomena may be interpreted in light of the fact that iron regulatory protein transiently facilitates replenishment of cytosolic iron in cells by increasing iron uptake through TfR and DMT1 while simultaneously decreasing iron sequestration in ferritin and suppressing iron export through $\mathrm{FPN}^{51}$ followed by stimulation of FRN1 expression by increased cytosolic iron. ${ }^{53}$

Next, we analyzed the state of iron in HGECs induced by Ang II by using a ferrous iron-specific fluorescence indicator, PG SK. Within cells, iron is stored in the protein ferritin or hemosiderin. Ferritin is a cytoplasmic protein consisting of 25 heterodimeric subunits of $\mathrm{H}$ and $\mathrm{L}$, and ferritin synthesis is regulated by iron regulatory protein
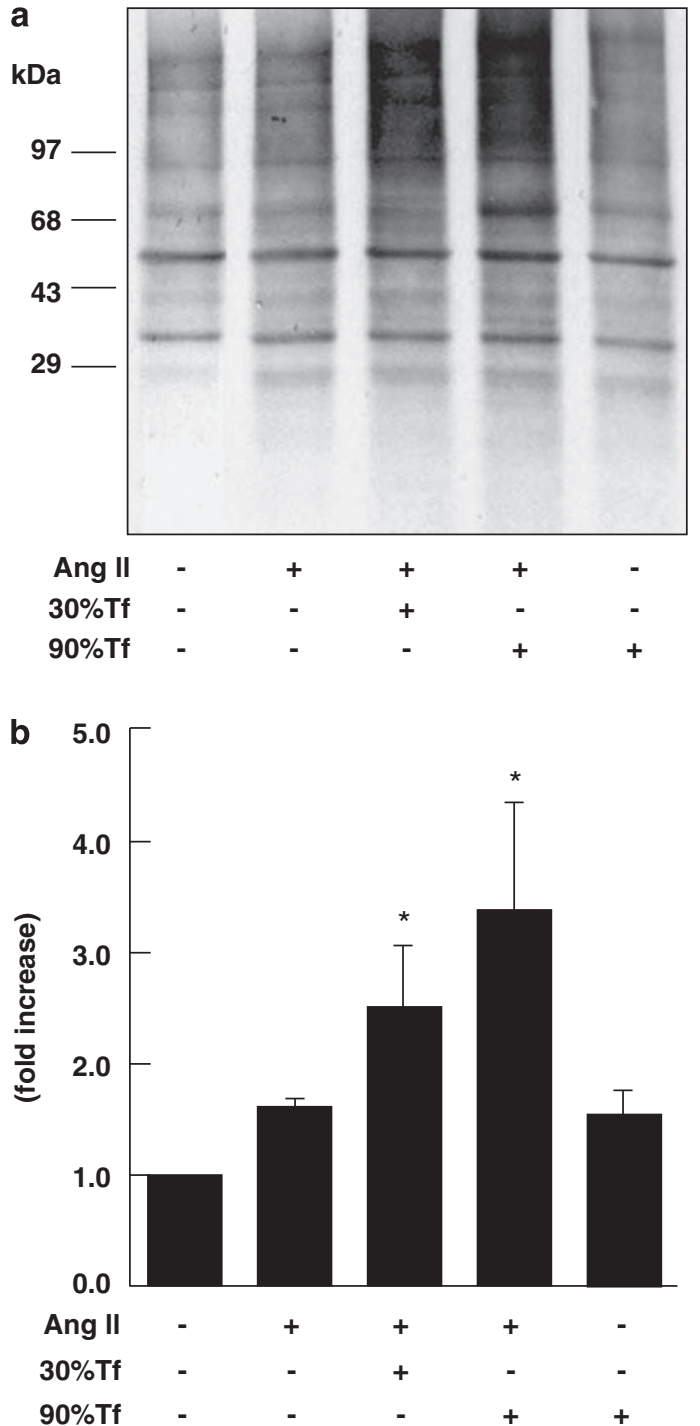

Figure 6 Effects of Ang II and Tf on protein carbonylation in HGECs. (a) Immunochemical detection of protein carbonyls in HGECs. HGECs were treated with $1 \mathrm{~nm}$ Ang II for $6 \mathrm{~h}$ with or without $50 \mu \mathrm{m}$ of 30 or $90 \%$ Tf. After the treatment, cells were subjected to 2,4-dinitrophenylhydrazine (DNPH) for the detection of carbonylated proteins as described in 'Methods' section. (b) Densitometric analysis of carbonylated proteins of the upper $68 \mathrm{kDa}$ proteins. Values were normalized by arbitrarily setting the densitometory of control cells (non-stimulated cells) to 1.0 (values the means \pm s.d. of, $n=5$, ${ }^{*} P<0.01$ vs. Ang II treatment cells).

activation when iron is excessive in cells. ${ }^{54}$ Ferritin stores up to 4500 ferric iron within the protein shell and releases iron as needed. ${ }^{55}$ Besides ferritin, a small amount of iron ( $<5 \%$ of total cellular iron) exists as the LIP. ${ }^{10}$ The LIP is free ferric iron bound to citrate or adenosine diphosphate, and a small amount of the LIP is reduced to ferrous iron, which is responsible for oxidation-reduction reactions and Fenton reaction. ${ }^{13,44}$ The results presented in Figures 1 and 2 show that Ang II-stimulated iron uptake into HGECs. In addition, it was expected that ferrous iron would be increased because Ang II facilitates $\mathrm{O}_{2} \bullet-$ production by the activation of $\mathrm{NOX}^{14-21}$ and $\mathrm{O}_{2}{ }^{\bullet-}$ participates to a certain extent in the reduction and release of ferrous iron from iron storage proteins within cells. ${ }^{25-27}$ Therefore, it is worth analyzing whether the Ang II increases the total amount of ferrous 
iron in HGECs. In this study, we followed the PG-derived fluorescence technique developed by Petrat et al. ${ }^{37}$ A slight increase in fluorescence levels of control HGECs indicated the existence of a small amount of free ferrous iron in the LIP under control conditions (Figures 3a, e and i). ${ }^{13,44}$ In all, $1 \mathrm{~nm}$ Ang II did not increase intracellular ferrous iron levels (Figures 3b, f and i). Interestingly, no significant increase in ferrous iron levels was observed when HGECs were treated with $90 \%$ Tf (Figure 3i) in spite of the fact that a large amount of iron was incorporated into HGECs (Figure 1b). In contrast, co-treatment with $1 \mathrm{~nm}$ Ang II and Tf significantly increased the intracellular ferrous iron levels in an iron level-saturation of Tf-dependent manner (Figures 3bf, c-g and i), and olmesartan treatment completely abolished ferrous iron formation.

In addition, the ferrous iron temporal pattern in HEGCs stimulated with $1 \mathrm{~nm}$ Ang II plus 90\% Tf, which showed a peak level at $6 \mathrm{~h}$ after treatment before declining (Figure 4), was the same as that of DMT1 (Figure 2). This is because DMT1 is the apical membrane iron transporter in intestinal epithelial cells, and the purpose of the endosomal iron transporter in other cells is to transfer endosomal free ferrous iron into the cytoplasm. ${ }^{6,56}$ These results (Figures 2 and 4) suggest that the $\mathrm{AT}_{1}$ receptor pathway, including NOX-derived $\mathrm{O}_{2}^{\bullet-}$ production $^{14-21}$ and DMT1 upregulation, has an important role in iron reduction ${ }^{25-27}$ and transportation ${ }^{56}$ in HGECs. For these reasons, it appears that the individual administration of each compound separately to HGECs did not increase the ferrous iron levels (Figure 3i).

Ang II has been reported to induce HO-1 expression in the kidney. ${ }^{57} \mathrm{HO}-1$ exerts cytoprotective effects against oxidative injury through antioxidant, anti-inflammatory, antiproliferative, antiapoptotic, immunomodulatory and vasorelaxant effects. ${ }^{58} \mathrm{HO}-1$ participates in cleavage of the heme ring producing biliverdin, $\mathrm{CO}$ and ferrous iron. The released iron becomes part of the intracellular iron pool and can be stored in ferritin or released by an iron exporter. ${ }^{59}$ If these reactions occurred, it would be expected that free ferrous iron is increased by Ang II treatment. However, in the present experiments, as shown in Figure 3, free ferrous iron level was the same as that of the control when HGECs were treated with $1 \mathrm{~nm}$ Ang II for $24 \mathrm{~h}$. Of course, we could not conclude that there was no contribution of HO-1 to free ferrous iron production in our experiments because FPN1, an iron export protein, was also upregulated by Ang II treatment for $24 \mathrm{~h}$ (Figure 2a). Further study is needed to confirm the contribution of HO-1 to labile ferrous iron production and subsequent oxidative stress.

Ferrous iron interacts with molecular oxygen to produce $\mathrm{O}_{2}{ }^{\bullet-}$ and ferric iron or with $\mathrm{H}_{2} \mathrm{O}_{2}$ to form ${ }^{\bullet} \mathrm{OH}$ by the Fenton reaction. Furthermore, ferric iron can be reduced to ferrous iron by $\mathrm{O}_{2}{ }^{\bullet-}$, which participates in the Harber-Weiss reaction ${ }^{22}$ to generate ${ }^{\bullet} \mathrm{OH}$, as mentioned in the Introduction section. Therefore, we tried to directly measure $\bullet \mathrm{OH}$ generation by EPR spectroscopy with a spin trapping method in HGECs treated with $1 \mathrm{~nm}$ Ang and $90 \%$ Tf. As shown in Figure 5, apparent EPR signals of the DMPO/ $/{ }^{\circ} \mathrm{OH}$ spin adduct were observed in the case of co-treatment with $1 \mathrm{~nm}$ Ang II and 90\% Tf, whereas separate administration of each compound to HGECs had not result. This $\mathrm{DMPO} /{ }^{\bullet} \mathrm{OH}$ spin adduct was completely suppressed in the presence of $0.1 \mathrm{~mm}$ DPI, a flavoenzyme inhibitor that also inhibits NOX (data not shown), because of suppression of the Fenton reaction through elimination of ferrous iron generation by NOXderived $\mathrm{O}_{2}{ }^{\bullet-}$. In addition, we measured the carbonylation of proteins in HGECs because protein carbonyl formation is accelerated by the existence of ferrous-adenosine complex ${ }^{60}$ or by ferrous iron with ROS. ${ }^{61}$ The degree of protein carbonyl formation was enhanced by co-administration of Ang II with Tf (Figure 6), which is in good agreement with the order of intracellular ferrous levels shown in Figure 3, suggesting that there were additional interactions between iron metabolism and oxidative stress in HGECs and that the generated ferrous iron participated in the protein carbonyl formation, as reported previously. ${ }^{60-62}$

The liver is the most important organ for iron storage, and cases of hepatitis $\mathrm{C}$ infection, ${ }^{63}$ alcoholic liver disease and non-alcoholic steatohepatitis are frequently associated with iron overload. ${ }^{30}$ Therefore, strategies for therapeutic iron reduction are in progress. Iron depletion through phlebotomy improves biochemical and histological outcomes in patients with chronic hepatitis $\mathrm{C}$ infection. ${ }^{64}$ In addition to phlebotomy, $\mathrm{AT}_{1}$ receptor blockers have come into use as an alternative remedy for iron-induced organ dysfunctions. Hirose et $a .^{32}$ first reported that olmesartan significantly attenuated the progression of non-alcoholic steatohepatitis. Izuhara et al. ${ }^{31}$ revealed that olmesartan inhibited iron deposition in tubules and interstitial cells of SHR/NDmcr-cp rats but that neither nifedipine nor atenolol did. These findings appear to be in accord with our results showing olmesartan inhibited the upregulation of iron-incorporating proteins, suppressed iron-export protein (FPN1) and inhibited formation of ferrous ions in cells.

In conclusion, Ang II not only induces production of ROS but also iron incorporation and a subsequent increase in labile ferrous iron in HGECs, events that may have an important role in endothelial dysfunction.

1 Schmieder RE, Hilgers KF, Schlaich MP, Schmidt BM. Renin-angiotensin system and cardiovascular risk. Lancet 2007; 369: 1208-1219.

2 Ishizaka N, Saito K, Furuta K, Matsuzaki G, Koike K, Noiri E, Nagai R. Angiotensin II-induced regulation of the expression and localization of iron metabolism-related genes in the rat kidney. Hypertens Res 2007; 30: 195-202.

3 Klausner RD, Ashwell G, van Renswoude J, Harford JB, Bridges KR. Binding of apotransferrin to K562 cells: explanation of the transferrin cycle. Proc Natl Acad Sci USA 1983; 80: 2263-2266.

4 Richardson DR, Ponka P. The molecular mechanisms of the metabolism and transport of iron in normal and neoplastic cells. Biochim Biophys Acta 1997; 1331: 1-40.

5 Armstrong NJ, Morgan EH. The effect of lysosomotrophic bases and inhibitors of transglutaminase on iron uptake by immature erythroid cells. Biochim Biophys Acta 1983; 762: 175-186.

6 Gunshin H, Mackenzie B, Berger UV, Gunshin Y, Romero MF, Boron WF, Nussberger S, Gollan JL, Hediger MA. Cloning and characterization of a mammalian proton-coupled metal-ion transporter. Nature 1997; 388: 482-488.

7 Ferguson CJ, Wareing M, Ward DT, Green R, Smith CP, Riccardi D. Cellular localization of divalent metal transporter DMT-1 in rat kidney. Am J Physiol Renal Physiol 2001; 280: F803-F814.

8 Donovan A, Lima CA, Pinkus JL, Pinkus GS, Zon LI, Robine S, Andrews NC. The iron exporter ferroportin/Slc40a1 is essential for iron homeostasis. Cell Metab 2005; 1: 191-200.

9 Cairo G, Recalcati S, Pietrangelo A, Minotti G. The iron regulatory proteins: targets and modulators of free radical reactions and oxidative damage. Free Radic Biol Med 2002; 32: 1237-1243.

10 Andrews NC. Probing the iron pool. Focus on 'detection of intracellular iron by its regulatory effect'. Am J Physiol Cell Physiol 2004; 287: C1537-C1538.

11 Kruszewski M. The role of labile iron pool in cardiovascular diseases. Acta Biochim Pol 2004; 51: 471-480.

12 Kakhlon O, Cabantchik ZI. The labile iron pool: characterization, measurement, and participation in cellular processes(1). Free Radic Biol Med 2002; 33: 1037-1046.

13 Yuan X, Cong Y, Hao J, Shan Y, Zhao Z, Wang S, Chen J. Regulation of LIP level and ROS formation through interaction of $\mathrm{H}$-ferritin with G-CSF receptor. J Mol Biol 2004; 339: 131-144.

14 Griendling KK, Sorescu D, Ushio-Fukai M. NAD(P)H oxidase: role in cardiovascular biology and disease. Circ Res 2000; 86: 494-501.

15 Vignais PV. The superoxide-generating NADPH oxidase: structural aspects and activation mechanism. Cell Mol Life Sci 2002; 59: 1428-1459.

16 Griendling KK, Minieri CA, Ollerenshaw JD, Alexander RW. Angiotensin II stimulates $\mathrm{NADH}$ and NADPH oxidase activity in cultured vascular smooth muscle cells. Circ Res 1994; 74: 1141-1148.

17 Lassegue B, Clempus RE. Vascular NAD(P)H oxidases: specific features, expression, and regulation. Am J Physiol Regul Integr Comp Physiol 2003; 285: R277-R297. 
18 Kondo S, Shimizu M, Urushihara M, Tsuchiya K, Yoshizumi M, Tamaki T, Nishiyama A, Kawachi H, Shimizu F, Quinn MT, Lambeth DJ, Kagami S. Addition of the antioxidant probucol to angiotensin II type I receptor antagonist arrests progressive mesangioproliferative glomerulonephritis in the rat. J Am Soc Nephrol 2006; 17: 783-794.

19 Jones SA, Hancock JT, Jones OT, Neubauer A, Topley N. The expression of NADPH oxidase components in human glomerular mesangial cells: detection of protein and mRNA for p47phox, p67phox, and p22phox. J Am Soc Nephrol 1995; 5: 1483-1491.

20 Kyaw M, Yoshizumi M, Tsuchiya K, Kirima K, Tamaki T. Antioxidants inhibit JNK and p38 MAPK activation but not ERK $1 / 2$ activation by angiotensin II in rat aortic smooth muscle cells. Hypertens Res 2001; 24: 251-261.

21 Rouhanizadeh M, Takabe W, Ai L, Yu H, Hsiai T. Monitoring oxidative stress in vascular endothelial cells in response to fluid shear stress: from biochemical analyses to microand nanotechnologies. Methods Enzymol 2008; 441: 111-150.

22 Haber F, Weiss J. The catalytic decomposition of hydrogen peroxide by iron salts. Proc $R$ Soc London, Ser A 1934; 147: 332-351.

23 Symons MCR, Gutteridge JMC. Free Radicals and Iron: Chemistry, Biology, and Medicine. Oxford University Press: New York, 1998.

24 Fridovich I. Oxygen toxicity: a radical explanation. J Exp Biol 1998; 201: 1203-1209.

25 Liochev SI, Fridovich I. The relative importance of $\mathrm{HO}^{*}$ and ONOO- in mediating the toxicity of O*. Free Radic Biol Med 1999; 26: 777-778.

26 Thomas CE, Morehouse LA, Aust SD. Ferritin and superoxide-dependent lipid peroxidation. J Biol Chem 1985; 260: 3275-3280.

27 Brieland JK, Fantone JC. Ferrous iron release from transferrin by human neutrophilderived superoxide anion: effect of $\mathrm{pH}$ and iron saturation. Arch Biochem Biophys 1991; 284: 78-83.

28 Seshiah PN, Weber DS, Rocic P, Valppu L, Taniyama Y, Griendling KK. Angiotensin II stimulation of $\mathrm{NAD}(\mathrm{P}) \mathrm{H}$ oxidase activity: upstream mediators. Circ Res 2002; 91: 406-413.

29 Wesseling S, Ishola Jr DA, Joles JA, Bluyssen HA, Koomans HA, Braam B. Resistance to oxidative stress by chronic infusion of angiotensin II in mouse kidney is not mediated by the AT2 receptor. Am J Physiol Renal Physiol 2005; 288: F1191-F1200.

30 Kohgo Y, Ohtake T, Ikuta K, Suzuki Y, Torimoto Y, Kato J. Dysregulation of systemic iron metabolism in alcoholic liver diseases. J Gastroenterol Hepatol 2008; 23(Suppl 1): S78-S81.

31 Izuhara Y, Nangaku M, Inagi R, Tominaga N, Aizawa T, Kurokawa K, van Ypersele de Strihou C, Miyata T. Renoprotective properties of angiotensin receptor blockers beyond blood pressure lowering. J Am Soc Nephrol 2005; 16: 3631-3641.

32 Hirose A, Ono M, Saibara T, Nozaki Y, Masuda K, Yoshioka A, Takahashi M, Akisawa N, Iwasaki S, Oben JA, Onishi S. Angiotensin II type 1 receptor blocker inhibits fibrosis in rat nonalcoholic steatohepatitis. Hepatology 2007; 45: 1375-1381.

33 Gillum RF, Sempos CT, Makuc DM, Looker AC, Chien CY, Ingram DD. Serum transferrin saturation, stroke incidence, and mortality in women and men. The NHANES I Epidemiologic Follow up Study. National Health and Nutrition Examination Survey. Am J Epidemiol 1996; 144: 59-68.

34 Ponka P, Schulman HM. Acquisition of iron from transferrin regulates reticulocyte heme synthesis. J Biol Chem 1985; 260: 14717-14721.

35 Aisen P. The transferrins. In Jacobs A, Worwood M (eds). Iron in Biochemistry and Medicine, Vol 2. Academic Press: New York, 1974 pp 87-129.

36 Bradford MM. A rapid and sensitive method for the quantitation of microgram quantities of protein utilizing the principle of protein-dye binding. Anal Biochem 1976; 72: 248-254.

37 Petrat $F$, Rauen $U$, de Groot $H$. Determination of the chelatable iron pool of isolated rat hepatocytes by digital fluorescence microscopy using the fluorescent probe, phen green SK. Hepatology 1999; 29: 1171-1179.

38 Yoshizumi M, Kogame T, Suzaki Y, Fujita Y, Kyaw M, Kirima K, Ishizawa K, Tsuchiya K, Kagami S, Tamaki T. Ebselen attenuates oxidative stress-induced apoptosis via the inhibition of the $\mathrm{C}$-Jun $\mathrm{N}$-terminal kinase and activator protein-1 signalling pathway in PC12 cells. Br J Pharmacol 2002; 136: 1023-1032.

39 Duling DR. Simulation of multiple isotropic spin-trap EPR spectra. J Magn Reson $B$ 1994; 104: 105-110.

40 Buss H, Chan TP, Sluis KB, Domigan NM, Winterbourn CC. Protein carbonyl measurement by a sensitive ELISA method. Free Radic Biol Med 1997; 23: 361-366.
41 Petrat F, de Groot H, Rauen U. Subcellular distribution of chelatable iron: a laser scanning microscopic study in isolated hepatocytes and liver endothelial cells. Biochem J 2001; 356: 61-69.

42 Floyd RA, Soong LM, Stuart MA, Reigh DL. Spin trapping of free radicals produced from nitrosoamine carcinogens. Photochem Photobiol 1978; 28: 857-862.

43 Andrews NC. Disorders of iron metabolism. N Engl J Med 1999; 341: 1986-1995.

44 Kohgo Y, Ikuta K, Ohtake T, Torimoto Y, Kato J. Body iron metabolism and pathophysiology of iron overload. Int J Hematol 2008; 88: 7-15.

45 Tsung SH, Rosenthal WA, Milewski KA. Immunological measurement of transferrin compared with chemical measurement of total iron-binding capacity. Clin Chem 1975; 21: 1063-1066

46 Zainal TA, Weindruch R, Szweda LI, Oberley TD. Localization of 4-hydroxy-2-nonenalmodified proteins in kidney following iron overload. Free Radic Biol Med 1999; 26: 1181-1193.

47 Abdel-Razik AE, Forty EJ, Balment RJ, Ashton N. Renal haemodynamic and tubular actions of urotensin II in the rat. J Endocrinol 2008; 198: 617-624.

48 Ikuta K, Zak O, Aisen P. Recycling, degradation and sensitivity to the synergistic anion of transferrin in the receptor-independent route of iron uptake by human hepatoma (HuH-7) cells. Int J Biochem Cell Biol 2004; 36: 340-352.

49 Ishizaka N, Aizawa T, Mori I, Taguchi J, Yazaki Y, Nagai R, Ohno M. Heme oxygenase-1 is upregulated in the rat heart in response to chronic administration of angiotensin II. Am J Physiol Heart Circ Physiol 2000; 279: H672-H678.

50 Miura J, Uchigata Y, Yokoyama H, Omori Y, Iwamoto Y. Genetic polymorphism of reninangiotensin system is not associated with diabetic vascular complications in Japanese subjects with long-term insulin dependent diabetes mellitus. Diabetes Res Clin Pract 1999; 45: 41-49.

51 Zhang DL, Hughes RM, Ollivierre-Wilson H, Ghosh MC, Rouault TA. A ferroportin transcript that lacks an iron-responsive element enables duodenal and erythroid precursor cells to evade translational repression. Cell Metab 2009; 9: 461-473.

52 Thomson AM, Rogers JT, Leedman PJ. Iron-regulatory proteins, iron-responsive elements and ferritin mRNA translation. Int J Biochem Cell Biol 1999; 31: 1139-1152.

53 Balla J, Jeney V, Varga Z, Komodi E, Nagy E, Balla G. Iron homeostasis in chronic inflammation. Acta Physiol Hung 2007; 94: 95-106.

54 Harrison PM, Arosio P. The ferritins: molecular properties, iron storage function and cellular regulation. Biochim Biophys Acta 1996; 1275: 161-203.

55 Koorts AM, Viljoen M. Ferritin and ferritin isoforms I: structure-function relationships, synthesis, degradation and secretion. Arch Physiol Biochem 2007; 113: 30-54.

56 Tabuchi M, Yoshimori T, Yamaguchi K, Yoshida T, Kishi F. Human NRAMP2/DMT1, which mediates iron transport across endosomal membranes, is localized to late endosomes and lysosomes in HEp-2 cells. J Biol Chem 2000; 275: 22220-22228.

57 Aizawa T, Ishizaka N, Taguchi J, Nagai R, Mori I, Tang SS, Ingelfinger JR, Ohno M. Heme oxygenase-1 is upregulated in the kidney of angiotensin II-induced hypertensive rats: possible role in renoprotection. Hypertension 2000; 35: 800-806.

58 Courtney AE, Maxwell AP. Heme oxygenase 1: does it have a role in renal cytoprotection? Am J Kidney Dis 2008; 51: 678-690.

59 Mendiburo MJ, Flores S, Pizarro F, Arredondo M. Heme oxygenase 1 overexpression increases iron fluxes in caco-2 cells. Biol Res 2006; 39: 195-197.

60 Blakeman DP, Ryan TP, Jolly RA, Petry TW. Protein oxidation: examination of potential lipid-independent mechanisms for protein carbonyl formation. J Biochem $\mathrm{Mol}$ Toxicol 1998; 12: 185-190.

61 Stadtman ER. Metal ion-catalyzed oxidation of proteins: biochemical mechanism and biological consequences. Free Radic Biol Med 1990; 9: 315-325.

62 Kartikasari AE, Georgiou NA, Visseren FL, van Kats-Renaud H, van Asbeck BS, Marx JJ. Intracellular labile iron modulates adhesion of human monocytes to human endothelial cells. Arterioscler Thromb Vasc Biol 2004; 24: 2257-2262.

63 Snover DC. Hepatitis C, iron, and hemochromatosis gene mutations. A meaningful relationship or simple cohabitation? Am J Clin Pathol 2000; 113: 475-478.

64 Franchini M, Targher G, Capra F, Montagnana M, Lippi G. The effect of iron depletion on chronic hepatitis C virus infection. Hepatol Int 2008; 2: 335-340. 